УДК 811.161 .1

DOI: 10.18101/2305-459X-2019-4-39-42

\title{
БЛОГ В ПУБЛИЦИСТИЧЕСКОМ ДИСКУРСЕ РУНЕТА: ЯЗЫК И ЖАНР
}

\author{
(c) Шумилина Светлана Александровна \\ аспирант, \\ Литературный институт им. А. М. Горького \\ Россия, 123104, Москва, Тверской бульвар, д. 25 \\ E-mail: shumilina.swet@yandex.ru
}

В статье рассматриваются жанрово-языковые особенности блога в публицистическом дискурсе Рунета. На основании данных аналитических ресурсов Сети, анализа авторских блогов и на практическом материале средств массовой информации, публикующих свои материалы в Рунете, дается краткий анализ признаков трансформации жанров публицистического дискурса на языковом и стилистическом уровнях. В статье затрагивается проблема снижения уровня использования традиционных публицистических жанров, таких как очерк, памфлет, фельетон, и появления универсальных жанровых форм публицистического текста, таких как блог. Статья отмечает положительные характеристики блога как особой формы публицистического жанра: подвижность, интерактивность, непрерывность информативного поля и др. Вместе с тем статья обозначает и негативные моменты данной формы: бесконтрольность использования лексических средств вплоть до применения ненормированной лексики.

Ключевые слова: интернет; Рунет; публицистика; дискурс; публицистический дискурс; жанр; блог; заметка; репортаж; очерк; фельетон.

\section{Для цитирования:}

Шумилина С. А. Блог в публицистическом дискурсе рунета: язык и жанр // Вестник Бурятского государственного университета. Язык. Литература. Культура. 2019. Вып. 4. С. 39-42.

Публицистический дискурс - один из самых распространенных в интернетсреде, поскольку имеет огромный тематический диапазон: все, что касается человеческой жизни (ее актуальной событийной составляющей), может стать причиной возникновения текста публицистического характера. Благодаря этому публицистические тексты в сетевой среде являются своего рода проводниками не только ментальных, но и функциональных, и языковых изменений, впитывающими и проявляющими все многообразие дискурсивных наслоений.

Тексты публицистического дискурса Рунета сегодня широко представлены большинством сетевых ресурсов: сайтами официальных СМИ, блогами, страницами социальных сетей и т. п. Публицистический дискурс Рунета не ограничивается блогосферой, но именно блог как достаточно новое явление в интернеткоммуникативном пространстве наиболее ярко отражает языковые изменения и жанровую трансформацию сетевой публицистики, о чем пишут в своих исследованиях современные лингвисты и филологи М. В. Иванова и Н. И. Клушина [Клушина, 2017, c. 121-129]. 
По данным Тор1000-Ру, опубликованным на сайте HotLog.ru 19 января 2019 года, верхние позиции рейтинга среди новостных сайтов Рунета заняли: 1 - «Яндекс новости», 2 - «Новости Mail.Ru», 3 - «Леди Mail.Ru - женский взгляд на мир», 4 - «РИА Новости», 5 - «Комсомольская правда — Digital» [2].

Каждый новостной ресурс имеет раздел с авторскими текстами, построенными по принципу блога: публикации ведутся регулярно, тексты имеют выраженную авторскую позицию, наблюдается разнообразие освещаемых тем, интересная подача информации каждым автором, наличие фото- и видеоматериалов. Сохраняя основные признаки публицистического стиля (логичность, образность, актуальность, эмоциональность, оценочность, призывность), тексты в интернет-пространстве подвергаются сильнейшей жанровой трансформации. Встретить сейчас в чистом виде очерк, статью, интервью, репортаж, эссе, фельетон в Рунете удается редко даже на сайтах официальных СМИ. Интернет-текст «приспосабливается к феноменологическим особенностям Глобальной Сети и получает особые медийные добавки (интерактивность, нелинейность, незавершенность и др.), что, в свою очередь, оказывает сильное влияние на его жанровую и стилистическую структуру» [Клушина, 2017, c. 125].

Сетевой публицистический дискурс разрушает границы жанров и производит особую форму обмена информацией между автором и читателем - блог [Иванова, 2018, с. 352]. Блог, появившись в коммуникативном пространстве как специфическая авторская хроника, очень быстро вышел за границы дневника и превратился в самостоятельный жанр публицистического дискурса, сочетающий в себе черты других публицистических жанров, даже тех, которые на сегодняшний день практически перестали существовать в чистом виде: очерка, эссе, фельетона.

Среди функциональной особенностей блога можно выделить его жанровую подвижность, возможность создавать публицистический текст, сочетающий в себе признаки заметки, статьи, очерка, эссе, фельетона, репортажа и т.п. Блог содержит признаки всех видов жанров публицистики: информационных, аналитических и художественно-публицистических. Это хорошо видно на примерах текстов различных ресурсов.

Так, на портале РИА Новости в авторском разделе от 24 января 2019 года размещена информация от Виктора Мараховского под названием «Мы обречены: олигархи объявили крестовый поход» [5]. Блогер-журналист дает анализ социально значимой актуальной проблемы, его текст сближается этим с проблемной статьей, для которой характерна логичность изложения на основе рассуждения, строящегося как доказательство главного тезиса. Рассуждение в данной публикации носит эмоциональный характер, его главная цель - воздействие на читателя (о трансляции авторской позиции как обязательной функции современного публицистического текста пишет и М. В. Иванова [Иванова, 2016, с. 90]). В этом ему помогает использование лексики как нормированного, так и ненормированного уровня: текст изобилует разговорной и инвективной лексикой.

"Рыночная элита" солидарна только в тех вопросах, которые касаются ее общих интересов. А так-то она состоит из конкурентов. Поэтому каждый миллиардер, который решит изменить правила и пожертвовать эффективностью ради "справедливого распределения", быстро превратится из миллиардера в миллионера. Потому что лох, потому что ослабил себя и должен проиграть [5]. 
Признаки информационных жанров (репортаж, заметка) также присутствуют в данной публикации. Публикацию Виктора Мараховского можно отнести сразу к нескольким разновидностям заметки: заметка-событие, мини-обозрение, так как в ней прослеживаются характерные для заметок данного вида черты — налицо рассказ о конкретном событии (Всемирный экономический форум в Давосе), а также присутствует ретроспекция, создающая совокупность нескольких, связанных между собой событий. Стилистические особенности данной публикации (эмоциональная вовлеченность автора в передаваемую информацию. Обилие оценочных суждений по поводу происходящих событий) сближают ее с репортажем.

Ведущие мировые СМИ на этой неделе энергично бичуют бедность и неравенство. Это традищия: ругать бедность принято в конще января, когда собирается Всемирный экономический форум в Давосе. Ихотя в этом году он провалился заранее (серьезные люди не приехали) - все, кто работает по теме, выстрелили очередными горькими разоблачениями [5].

Виктор Мараховский для создания образного, конкретно-чувственного представления о проблеме, активно использует в тексте приемы и средства, характерные для художественно-публицистических жанров (очерк, фельетон). Текст Мараховского - это и снимок сегодняшнего дня, сделанный публицистическим объективом автора. И если в художественной литературе очерк как жанр - сегодня большая редкость, то блог один из немногих вариантов его сохранения, пусть и в несколько измененном виде. Текст пропитан иронией и в адрес сильных мира сего, и в адрес тех, кто им верит. Это раскрывает в нем черты фельетона. Яркий стилистический прием, свойственный фельетону, вскрытие проблемы социально-политического свойства через антитезу, также присутствует в данной публикации: гуманистические заявления и действия олигархов приводят к прямо противоположному результату падению уровня жизни подавляющего большинства населения планеты.

Но фокус в том, что эти добрые богатые люди убеждены: соииальные изменения достигаются не государственным или общественным регулированием, а доброй волей победителей - и строго через механизмы свободного рынка. То есть борьбой с неравенством командуют те, кто от неравенства больше всех выигрывает. И - сюрприз - у них получается строго наоборот: неравенство только pacmem [5].

Блоги (авторские рубрики) ресурсов других СМИ точно так же представляют массовому читателю публикации, являющиеся текстами со смешанными жанрововидовыми характеристиками публицистики.

Авторские блоги публицистического дискурса Рунета в отличие от авторских рубрик СМИ более свободны в плане самовыражения и применения языковых средств. Даже если автор придерживается некоторой «внутренней самоцензуры», то читатели в комментариях к публикациям демонстрируют весь арсенал языковых средств, вплоть до использования инфернальной лексики. Так, блогер ТЕМА, занимающий на данный момент времени 4 место в рейтинге блогеров Рунета [6], в публикации «Дожитие» от 21.01.19 пишет:

Дожсттие - это этап жизни, когда уже понятно, что скоро помирать... Что я там захочу за месяи до смерти? Вискаря, *** и заката на Шантарских островах? [7]. 
Читатель Сергей С. отвечает на это в комментариях: «Планирую дожить до 75-80 лет. А там уже и сдохнуть не стылдо Еще хотелось бы не *** окружаюших $\kappa$ этому времени» [7] (орфография и пунктуация представлены авторские, непечатная лексика заменена символом «***»).

Таким образом, блог сегодня активно отбирает ведущие позиции у интернетресурсов официальных СМИ с их традиционными представлениями о публицистических жанрах. Интернет в целом и Рунет в частности - это прежде всего коммуникативная среда, в которой информация не только подается автором, но и активно обсуждается читателем. Блог как интерактивный ресурс публицистического дискурса максимально отвечает этим требованиям. Блог как новый интернет-жанр публицистического дискурса нуждается в основательном изучении с точки зрения жанрового разнообразия и специфики языкового применения.

\section{Литература}

1. Клушина Н. И., Иванова М. В. Трансформация медийных жанров в коммуникативном пространстве Интернета // Вестник РФФИ. Гуманитарные и общественные науки. № 3(88). 2017.

2. URL: http://top1000-ru.hotlog.ru (дата обращения: 20.01.2019).

3. Иванова М. В. Публицистика и постпублицистика // Журналистика в 2017 году: творчество, профессия, индустрия: материалы междунар. науч.-практ. конф. (Москва, МГУ им. М. В. Ломоносова, 5-7 февраля 2018 г.). Т. 1. М.: Изд-во МГУ, 2018. С. 195-196.

4. Иванова М. В. Речь журналистов электронных СМИ // Учимся говорить порусски. Проблемы современного языка в электронных СМИ: сб. науч. ст. М.: Изд-во МГУ им. М. В. Ломоносова, 2016. С. 86-93.

5. URL: https://ria.ru (дата обращения: 24.01.2019).

6. URL: http://vovkasolovev.ru/top (дата обращения: 21.01.2019).

7. URL: http://tema.livejournal.com (дата обращения: 21.01.2019).

\section{BLOG IN THE JOURNALISTIC DISCOURSE OF RUNET: THE LANGUAGE AND THE GENRE}

\section{(C) Svetlana Alexandrovna Shumilina}

Federal State Budget Educational Institution of Higher Education the «Maxim Gorky Institute of Literature and Creative Writing» 25, Tverskoy boulevard, Moscow,123104, Russia

E-mail: shumilina.swet@yandex.ru

The article includes genre and language features of the blog in the journalistic discourse of Runet. Based on the data of analytical resources of the Network, analysis of author's blogs and on the practical material of mass media, publishing their materials in Runet, a brief analysis of the signs of transformation of genres of journalistic discourse at the linguistic and stylistic levels is given. The article deals with the problem of reducing the level of use of traditional journalistic genres, such as essay, pamphlet, satire, and the emergence of universal genre forms of journalistic text, such as blog. The article notes the positive characteristics of the blog as a special form of journalistic genre: mobility, interactivity, continuity of the informative field, etc. At the same time, the article also denotes the negative aspects of this form: uncontrolled use of lexical means up to the use of irregular vocabulary.

Keywords: Internet; Runet; Journalistic; discourse; journalistic discourse; genre; blog; note; reportage; essay; feuilleton. 